\title{
PENGARUH PERSENTASE VOLUME SERAT ECENG GONDOK DAN SERAT PINANG TERHADAP SIFAT MEKANIK DAN BIODEGRADASI KOMPOSIT HIBRID MATRIK EPOKSI
}

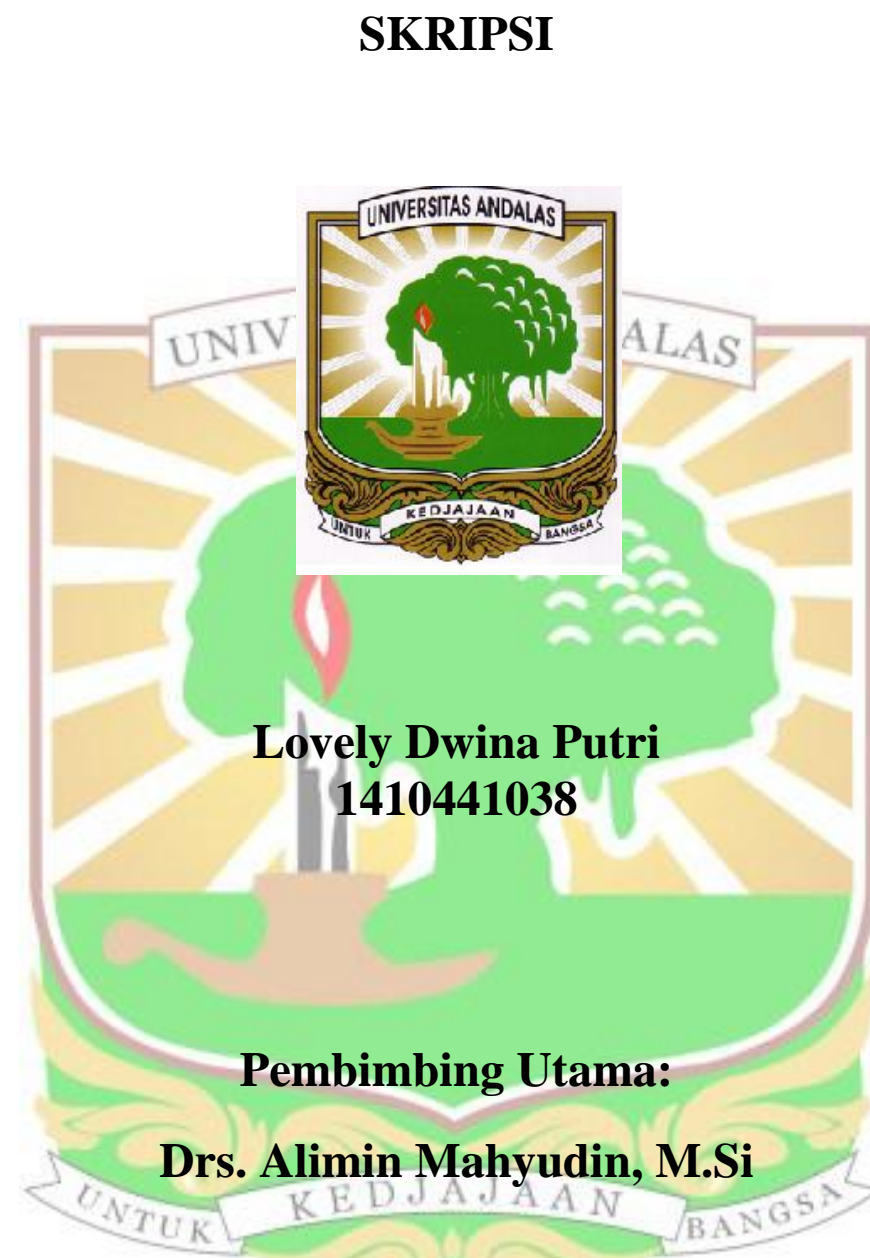

\author{
JURUSAN FISIKA \\ FAKULTAS MATEMATIKA DAN ILMU PENGETAHUAN ALAM \\ UNIVERSITAS ANDALAS \\ PADANG
}




\title{
PENGARUH PERSENTASE VOLUME SERAT ECENG GONDOK DAN SERAT PINANG TERHADAP SIFAT MEKANIK DAN BIODEGRADASI KOMPOSIT HIBRID MATRIK EPOKSI
}

\begin{abstract}
ABSTRAK
Material komposit serat alam banyak diteliti dikarenakan ramah lingkungan dibandingkan komposit serat sintesis. Pada penelitian ini, dilakukan pengujian meliputi uji kuat tarik, regangan, modulus elastisitas, kuat impak, dan uji biodegradasi. Dari hasil pengujian didapatkan nilai kuat tarik terbesar pada volume serat $10 \%$ yaitu 27,27 MPa, nilai kuat tarik komposit mengalami penurunan veiring dengan bertambahnya volume serat. Modulus elastisitas tertinggi pada volume serat $0 \%$ sebesar $343,1 \mathrm{MPa}$. Nilai kuat impak tertinggi pada volume serat $40 \%$ sebesar $0,0161 \mathrm{~J} / \mathrm{mm}^{2}$. Nilai kuat impak komposit dipengaruhi oleh volume serat yang diberikan, nilai kuat impak meningkat seiring dengan bertambahnya volume serat. Nilai biodegradasi tertinggi pada volume serat $40 \%$ sebesar $0,0102 \%$. Nilai degradasi komposit sangat dipengaruhi oleh volume sarat yang diberikan, semakin banyak serat maka semakin besar nilai degradasi yang diperoleh. Nilai kekuatan tarik dan harga impak komposit yang didapatkan sudah memenuhi standar plastik yang digunakan pada dasboard mobil.
\end{abstract}

Kata kunci: serat pinang, serat eceng góndok, epoksi, komposit hibrid, biodegradasi.

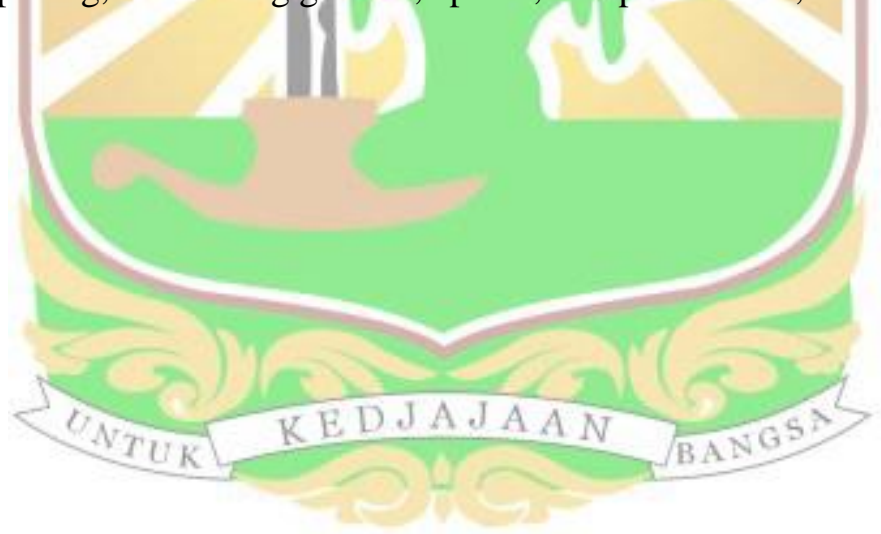




\title{
THE EFFECT OF THE PERCENTAGE OF VOLUME OF WATER HYACINTH FIBER AND ARECA NUT FIBER ON MECHANICAL PROPERTIES AND BIODEGRADATION OF HYBRID COMPOSITE OF EPOXY MATRIX
}

\begin{abstract}
Natural fiber composites materials have been studied due to their environmental friendliness compared to synthetic fiber composites. In this research, testing included tensile strength, strain, modulus of elasticity, impact strength, and biodegradation test. From the test results obtained the largest tensile strength ${ }_{\mathrm{B}}$ value at $10 \%$ fiber volume which is $27,27 \mathrm{MPa}$, composite tensile strength values decreased with increasing fiber volume. The higest modulus of elasticity at $0 \%$ fiber volume is $343,1 \mathrm{MPa}$. The higest impact strength value is $40 \%$ fiber volume of $0,0161 \mathrm{~J} / \mathrm{mm}^{2}$. The values of composites impact strength is influenced by the volume of fiber given, the value of impact strength increases with increasing volume of fiber. The highest biodegradation value was at $40 \%$ fiber volume of $0,0102 \%$. Composites degradation value are strongly influenced by the volume of fiber given, the more fiber the greater the degradation value obtained. The value of tensile strength and impact strength of composites obtained has met the standard of plastic used on the car dasboard.
\end{abstract}

Keywords: areca fiber, water hyacinth fiber, epoxy,hybrid composite, biodegradation.

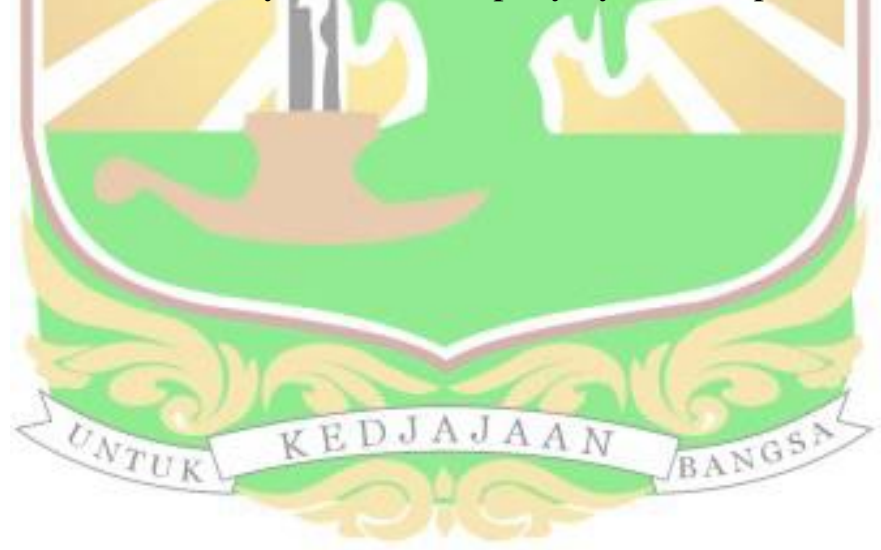

